\title{
An Investigation on Effect of Share Price Change on Investment Decision in Rwanda Stock Exchange
}

\author{
NSENGIYERA Daniel \\ University of Kigali (UoK), School Of Education, Department Of Postgraduate \\ Accounting and Finance Option, P.O.Box 2611 Kigali, Rwanda
}

\begin{abstract}
This study focused on investigating the effect of share price change on investment decision in Rwanda Stock Exchange. An evaluation was needed to find out whether the share price change is effective and whether it has really an impact on investment decision in RSE. The main aim of this study was to analyse the effect of share price change on investment decision in Rwanda Stock Exchange. Relevant methods (descriptive statistics, correlation, and regression analyses) were used to gather necessary data from various sources, either primary or secondary sources from a sample size of 394 respondents selected according to the formula of Morgan. This sample was chosen because it was easier to manage, and it was enough to generate findings as well as to generalize the findings to a bigger population. An explanatory descriptive design was used, data were collected by face-to-face questionnaire, and then the collected data were analysed and interpreted through SPSS (Statistical Package for the Social Sciences). The aim of this research was to see whether share price change has a greater influence on investment decision in the Rwanda Stock Exchange. Based on the results of empirical analysis about the causeeffect between the share price change and investment decision, the findings revealed that there was evidence that the chosen determinants that are: company news, demand and supply forces, innovation, inflation, and firm's financial performance, have significant effect on share price and consequently affect investment decision. Thus, the study concluded by showing to what extent the share price change is affecting the investment decision in Rwanda Stock Exchange.
\end{abstract}

Keywords: Company news, Demand and supply forces, Innovation, Inflation, Financial services, and Investment decision.

DOI: $10.7176 / \mathrm{RJFA} / 12-22-02$

Publication date: November 30th 2021

\section{INTRODUCTION}

Companies seek to be listed on the Stock Exchange when they need to raise money. New companies may be looking for start-up capital, while older companies may be seeking additional funds for expansion. Moreover, well established firms may want to let their owners sell out their stake, or part of it, to other investors. Buying shares therefore means that the investor has taken a stake in the company. The company share gives the buyer a stake in the company and the entitlement to be paid a proportion of its profits (dividend). The value of shares in the company therefore outperforms all other forms of investment over a reasonable period of time (White, 2007).

The nature of stock prices causes price fluctuations which have direct and indirect implications on investment decisions. Price changes can be caused by factors such as interest rates, foreign exchange rates; equity turnover, investor mood, capital structure and corporate announcements (Gatua, 2013). They are also attributed to the historical data based on events (Jagongo 2013).

Factors affecting investment decisions in stock exchanges have been subject to extensive studies. While some scholars (Ariful et al., 2015; Khan et al., 2015; Khaneman and Tverbsky, 1986; Malkiel, 2003) explain investment decisions by considering economic aspects, others (Awais et al., 2016; Hoang and Nguyen, 2014; Larrick and Bores, 1995; Talal et al., 2016; Yates, 1990) have carried out analyses considering sociodemographic or psychological factors in line with the behavioural finance theory.

However, the novelty of our study is that it considers that investment decisions are a result not only of economic factors, but also psychological, social, and demographic ones. The first category of academic studies analyses investment decisions and maintains that investors are rational and utility maximizing. They hold stocks because they are willing to hedge against the inflationary erosion of purchasing power, and more importantly, because they expect long-term substantial capital growth and dividend yields. In this regard investments in the capital market can be undertaken by an investor for three basic objectives: wealth maximization; maintaining liquidity; and risk minimization. This implies that a rational investor is influenced by these objectives when making investment decisions (Reilly and Brown, 2011; Teweles and Bradley, 1998).

The second category of scholars argues that investment decisions are subject to irrational behaviour. They contend that although much of economic and financial theory is based on the notion that individuals act rationally and consider all available information in the decision-making process, there is a surprisingly large amount of evidence which shows that this is not the case in many instances. Their findings reveal that there are biases in decision-making. These biases have implications on whether to invest in stock market related products, the extent 
of such investments and the nature of the investments. The biases could cause investors to take poor decisions or financial advisers to give poor advice (Bernstein, 1998; Elvin, 2004; Redhead, 2008).

However, Branston and Greenwood (2013) concluded that in general, when other determinants of investment are controlled, share prices tend to have a positive effect on investment. Therefore, share price change influences Investment decisions because they are a function of macroeconomic announcements, price-related evaluation, and the choice of investment strategy and behavioral patterns of the investors (Phau and Poon, 2000).

In the views of Lease et al., (1974) and Lewellen et al. (1977) individuals are "investors" rather than "traders" who are long-term minded and give little interest to short-term yields, and whose main source of information is through fundamental or technical analysis. Antonides and Van Der Sar, (1990) reveal that the perceived risk of an investment is lower if an asset has recently increased in value. In the United Kingdom, for instance, share prices are underpinned by dividends (White, 2007).

Besides, Hodge (2000), Doritrius (2007); Naggy and Obenberger (1994), add that investors do not decide to buy shares based on the risk of price fluctuation. Francis and Soffer (1997) [15] Krishnan and Booker (2002), echoes in and reveal that the investment decisions are affected mostly by the personal financial needs and analyst recommendations, with other factors occupying a miniature role. Therefore, a decrease in share prices will not lead to an immediate drop in investment because the funds are already committed.

Fischer and Merton (1984) in their studies on the financial variables concluded that the share market was a prominent cause of investment. Mullins and Wadhwani (1989) conducted a study and revealed that in the United States and in the United Kingdom, stock markets have a much greater influence on the investment process. Morck et al. (1990) concluded that share prices add little explanatory power to the investment equation once other influences are considered.

Buigut, et al, (2013) revealed that debt, equity, and gearing ratio were significant determinants of share prices. Fischer and Merton (1984) and Doan et al. (1983) found a causal relationship between share returns and investment decision, even when other traditional explanatory variables are added to the investment equation. From there it can be observed that investment decision is not only based on share prices but based on different variables. Kadiyala and Rau (2004) investigated investor reaction to corporate event announcements.

They concluded that investors appear to under-react to prior information as well as to information conveyed by the event, leading to different patterns. Baker and Haslem, (1973) argue that investors are primarily concerned with expectations about the future, considering earnings projection and historical data to be of high interest to investors. On the other hand, research by Lee and Tweedie, $(1975,1976$, and 1977) reveal that the public faces problems in understanding financial reporting in the corporate sector. Blume and Friend, (1978) provided evidence from their study that both price and earnings volatility are the primary measures of risk employed by individuals. Although, extensive studies have been carried out on effect of share price change on investment decision, their findings are not conclusive because they lack, a comprehensive methodology and in-depth analysis. It is this reason that the researcher interested to comprehensively investigate how investors react to share price change by allocating their investment.

\section{METHODOLOGY}

An explanatory descriptive design was used in this study. The data were collected using questionnaire to interviewer 394 respondents. Questionnaires were filled in alongside the interview by the researcher. Data were analyzed by using of statistical package for social sciences, version 20.0, and other statistical methods (descriptive statistics, correlation, and regression analyses) and considered p-value 0.5 as the level of significance at $95 \%$ confidence interval $(95 \% \mathrm{CI})$.

\section{DISCUSSION}

Perception of respondents on company news, demand and supply forces, innovation, inflation, and financial performance.

The determinants of share price change are but not limited to Company news, Demand and supply forces, Innovation, Inflation, and financial services. The research gave the respondents various statements regarding share price change and investment decision on Rwanda Stock exchange.

Table 1. The determinants of share price change. $(n=394)$

\begin{tabular}{|c|c|c|}
\hline S/N Response & Number of respondents & Percentage \\
\hline Company news & 117 & $29,70 \%$ \\
\hline Demand and supply forces & 109 & $27.77 \%$ \\
\hline Innovation & 62 & $15.74 \%$ \\
\hline Inflation & 56 & $14.21 \%$ \\
\hline Financial performance & 50 & $12.69 \%$ \\
\hline Total & 394 & $100 \%$ \\
\hline
\end{tabular}

The analysis of the above table revealed that among the determinants of share price change, the most affecting 
are company news and demand and supply forces, and therefore are the ones that are affecting the investment decision.

Table 2: Respondents' responses on effect of companies' news on investment decision in Rwanda Stock. $(\mathbf{n}=394)$

The respondents were asked to indicate to what extent they agreed or disagreed with each of the following statements. Mean (Weighted average) and standard deviation were used to analyze the data.

\begin{tabular}{|l|l|l|l|}
\hline Effect of companies' news on investment decision in Rwanda Stock & Mean & SD & Interpretation \\
\hline $\begin{array}{l}\text { There is no significant effect between company news and investment decision } \\
\text { in Rwanda Stock exchange }\end{array}$ & 1.4 & 0.43 & Disagree \\
\hline $\begin{array}{l}\text { There is no significant effect between supply and demand and investment } \\
\text { decision in Rwanda Stock Exchange }\end{array}$ & 1.7 & 0.42 & Disagree \\
\hline $\begin{array}{l}\text { There is no significant effect between innovation and investment decision in } \\
\text { Rwanda Stock Exchange }\end{array}$ & 1.06 & 0.41 & Disagree \\
\hline $\begin{array}{l}\text { There is no significant effect between inflation and investment decision in } \\
\text { Rwanda Stock Exchange }\end{array}$ & 1.09 & 0.46 & Disagree \\
\hline $\begin{array}{l}\text { There is no significant effect between financial performance of the firms and } \\
\text { investment decision in Rwanda Stock Exchange }\end{array}$ & 1.02 & 0.43 & Disagree \\
\hline
\end{tabular}

Note: $[1-1.8]=$ Very low mean; $[1.9-2.6]=$ Low mean; $[3.5-4.2]=$ High mean; $[4.3-5$ and above $]=$ Ver high mean.

From the above table, it was also noted that all the respondents disagreed with all the statements regarding that there is no significant effect between company news, supply and demand, innovation, inflation, and financial performance with investment decision in Rwanda Stock Exchange. review from this table then shows the disagreement level of respondents.

Table 3: Correlation Matrix showing the relationship between share price change and Investment decision in Rwanda Stock Exchange

Share price change

Pearson Correlation Sig. (2-tailed)

$\mathrm{N}$

Investment decision

Pearson Correlation
Sig. (2-tailed)
N

\section{Share price change}

1

$.997 * *$

.000

394

\author{
Investment decision \\ $.997 * *$ \\ .000 \\ 394
}

1

394

Correlation is significant at the 0.01 level (2-tailed)

Pearson correlation coefficient, $(\mathrm{r}=0.997)$ shown that there was a very high significant relationship $(\operatorname{sig}=0.000)$ between share price change and investment decision. This was an indication that if share price policies are maintained or improved, investment decision would be enhanced. This relationship indicated that a directional change in the independent variable (share price change) leads to the same directional change in the dependent variable (investment decision).

\section{CONCLUSION}

This study investigated the effect of share price change on investment decision in Rwanda Stock Exchange. The motivation for the study was rooted in the observed insignificant investment in shares in RSE in recent years as well as the need to understand the behavior of investors in Rwanda Capital Market and the factors that influence them to invest in shares. With the hope that this will provide insights into how to develop more effective marketing programmes for shares sales in Rwanda and elsewhere.

The results shown that the top five factors that have influenced the investment decisions of the respondents in order of ranking are companies' news, demand and supply forces, innovation, inflation, and financial performance of firms. The regression analysis used in this research, shown a significant relationship between share price indicators and investment decision in RSE.

The result from the study, shown the major problems that are challenging the investments but most one that investors are facing is the level of decreasing of share prices on all stock listed companies in Rwanda, however others are: lack of public awareness in investing in shares and lack of proper share market operational framework by the Capital Market Authority.

The research concluded that there is a positive relationship between share price change and investment decision in Rwanda Stock Exchange. Therefore, this generally means that without share price change, the investment decision on the Rwanda Stock Exchange might be very critical. 


\section{REFERENCES}

Antonides and Van Der Sar, (1990). Individual expectations, risk perception and preference in relation to investment decision making. Journal of Economic Psychology, 1990, vol. 11, issue 2, 227-245

Ariful, Md.I, Md. R Imtiaj, and Y. Salahuddin (2015). Investors`Investment Decisions. Vol. 15, No 4 C (2015).

Awais, M. Laber, M.F., Rasheed, N. and Khursheed, A. (2016): "Impact of Financial Literacy and Investment Experience on Risk Tolerance and Investment Decisions: Empirical Evidence from Pakistan," International Journal of Economics and Financial Issues, Econjournals, vol. 6(1), pages 73-79.

Baker, H.K and Haslem, J.A. (1973), "Information needs of individual investors", Journal of Accountancy, Vol.136, pp.64-90.

Bernstein, P. L. (1998). Stock market risk in a Post Keynesian world. Journal of Post Keynesian Economics, 21(1), $15-24$.

Blume and Friend, 1978. All their eggs in one basket: Portfolio diversification of US households. The Journal of Finance, 1978 - Wiley Online Library.

Buigut, K. Soi, N. Koskei, I. \& Kibet, J. (2013). The Effect of Capital Structure on Share Price on Listed Firms in Kenya. A Case of Energy Listed Firms. European Journal of Business and Management, Vol. 5, No. 9, 2013.

Dimitrios, I. M., (2007). Investors' behavior in the Athens Stock Exchange. In the Journal of Accountancy, Vol. 120, pp.67-72. Econometrics.

Fischer S \& Robert C. Merton, (1984). "Macroeconomics and Finance: The Role of the Stock Market," NBER Working Papers 1291, National Bureau of Economic Research, Inc.

Hodge, F.D, (2000) "Investors' perceptions of earnings quality, auditor independence, and the usefulness of audited financial information" Accounting Horizons, Vol.17

Jagongo, A. \& Mutswenje, V. (2014). A Survey of the factors influencing investment decisions: The case of individual investors at the NSE. In the International Journal of Humanities and Social Science Vol. 4 No. 4.

Kadiyala, P. and Rau, R. (2004). Investor reaction to corporate event announcement: Under reaction or overreaction? In the Journal of Business, Vol.77.

Kahneman, D. and A. Tversky 1979, "Prospect Theory: An Analysis of Decision under Risk"

Lee, T.A and Tweedie, D.P. (1975A). "Accounting information and investigation of private shareholder usage", Accounting\& Business Research, Autumn.

Lewellen, W.G., Lease, R.C and Schlarbaum, G.G. (1977), "Patterns of investment strategy and behavior among individual investors", Journal of Business, Vol 50 No 3 pp296-333.

Morck et al. (1990a). The Stock Market and Investment: is the Market a Sideshow? Brookings Papers on Economic Activity, 157-215.

Mullins, M\& Wadhwani, Sushil B., (1989). "The effect of the stock market on investment: a comparative study," European Economic Review, Elsevier, vol. 33(5), pages 939-956, May.

Reilly, F.K. and K.C. Brown (2011). Investment analysis and portfolio management. 10th Edition, Cengage Learning, South-Western Educational Publishing.

White, J. (2007). Investing in shares and stocks. Seventh edition. Oxford: How to Books. Rosenow, B. \& Weber, P. (2006). Large stock price changes: volume or liquidity? In the Quantitative Finance, Vol. 6, No. 1, 7-14. Germany: Rutledge. 